\title{
Ohesitas Sebagai Faktor Risiko Sindrom Syok Dengue
}

\author{
Elmy S, BNP Arhana, IKG Suandi, IGL Sidiartha \\ Bag/SMF Ilmu Kesehatan Anak FK UNUD/RSUP Sanglah Denpasar
}

Latar belakang. Beberapa peneliti melaporkan bahwa anak obese memiliki risiko mengalami SSD (sindrom syok dengue) lebih tinggi dibandingkan anak non-obese, walaupun hal ini masih kontroversial.

Tujuan. Mengetahui risiko SSD pada anak obese dibandingkan dengan anak non-obese.

Metode. Rancangan kasus kontrol telah dilakukan terhadap 51 anak SSD sebagai kasus dan 51 anak DBD (demam berdarah dengue) non syok sebagai kontrol. Data diambil dari rekam medik pasien anak berumur kurang dari 12 tahun dengan DBD dan SSD dan dirawat inap di bagian anak, Rumah Sakit Umum Pusat Sanglah Denpasar periode tanggal 1 Januari sampai 31 Juli 2008. Obese dan non-obese ditentukan berdasarkan pengukuran berat badan per tinggi badan. Risiko ditentukan dengan menghitung rasio odds dan analisis multivariat dilakukan terhadap faktor-faktor yang berpengaruh terhadap SSD. Tingkat kemaknaan yang diinginkan apabila $p<0,05$ dan interval kepercayaan $95 \%$.

Hasil. Rerata umur subjek pada kasus $(7,5 \pm 2,5)$ tahun, kontrol $(7,7 \pm 2,9)$ tahun $(p=0,767)$. Jenis kelamin laki-laki 26 (51\%), kontrol 27 orang (52,9\%)(p=0,843). Infeksi sekunder 84,3\% dan 64,7\% pada kontrol $(p=0,693)$. Pasien obese yang mengalami SSD $78,9 \%$ pada non-obese $43,4 \%(p=0,005)$, rasio odds 4,9 (IK 95\% 1,5-16,0). Pada analisis multivariat, didapatkan hanya status gizi yang bermakna berpengaruh terhadap terjadinya SSD dengan $p=0,009$.

Kesimpulan. Obesitas adalah faktor risiko terjadinya syok pada DBD. Risiko SSD pada anak obese 4,9 kali lebih besar dibandingkan dengan anak non-obese.(Sari Pediatri 2009;11(4):238-43).

Kata kunci: sindrom syok dengue, obesitas, faktor risiko

\footnotetext{
Alamat korespondensi

Dr. Elmy Saniathi Bag/SMF Ilmu Kesehatan Anak FK UNUD/RSUP Sanglah Denpasar Jln. Pulau Nias Denpasar Bali. Telepon/Fax: 0361244038 atau 0361-257387 E-mail:
}

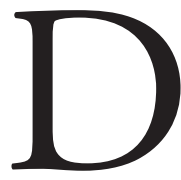

emam berdarah dengue (DBD) merupakan masalah kesehatan masyarakat karena angka kesakitan dan kematian masih tinggi serta merupakan 10 penyebab kesakitan dan kematian di Asia Tenggara dan Pasifik Barat dengan angka kematian antara 1\%-30\%. ${ }^{1}$ Sekitar 2,5 milyar penduduk di 100 negara berisiko terinfeksi, 20-100 juta penduduk terinfeksi virus dengue, dan 250-500 ribu penduduk menderita DBD 
pertahun. ${ }^{2}$ Kematian akibat DBD sekitar 24 ribu dan menjadi epidemi setiap 3-5 tahun sekali terutama saat musim hujan. Setengah dari populasi negara-negara di dunia merupakan endemik dengue. ${ }^{3,4}$ Indonesia juga merupakan daerah endemis DBD dengan angka kejadian per 100.000 penduduk 0,08 pada tahun 1968 menjadi 35,2 pada tahun $1998 . .^{5}$ Angka kejadian di Denpasar 59,9 per 100.000 orang pada tahun 1997 dan angka kematian tertinggi 1,7\% pada tahun yang sama, dengan puncak penyakit pada bulan April dan Mei. ${ }^{6}$ Secara nasional DBD merupakan 1 dari 8 penyebab kematian tertinggi akibat penyakit infeksi. Penyakit DBD mempunyai kemungkinan 5\% menyebabkan kematian tapi jika berkembang menjadi sindrom syok dengue (SSD), angka kematian meningkat menjadi $40 \%-50 \% .^{7,8}$

Pada DBD terjadi kebocoran plasma, pada SSD kebocoran plasma sangat masif sehingga menyebabkan terjadinya syok hipovolemik. Kejadian syok akibat DBD di berbagai rumah sakit di Indonesia bervariasi antara 11,2\%-42\%. Banyak faktor yang mempengaruhi terjadinya syok yaitu serotipe virus dengue, umur, jenis kelamin, ras, genetik, daya tahan tubuh, infeksi primer atau sekunder, penyakit lain yang menyertai, serta status nutrisi. ${ }^{9}$ Status nutrisi mempengaruhi derajat berat ringannya penyakit berdasarkan teori imunologi yaitu gizi baik meningkatkan respon antibodi. Reaksi antigen dan antibodi yang berlebihan menyebabkan infeksi dengue lebih berat. ${ }^{9}$ Walaupun demikian, mekanisme peningkatan SSD pada obesitas masih belum jelas. Apakah hal ini berhubungan dengan pelepasan sitokin pro-inflamasi oleh sel adiposit jaringan lemak? Sel adiposit jaringan lemak mensekresikan dan melepaskan sitokin pro-inflamasi yaitu TNF $\alpha$ (tumour necrosis factor $\alpha$ ) dan beberapa interleukin (IL) yaitu IL-1 $\beta$, IL-6, dan IL-8. Pada obesitas terjadi peningkatan ekspresi TNF $\alpha$ dan IL-6. Salah satu efek TNF $\alpha$ adalah meningkatkan permeabilitas kapiler sedangkan pada SSD juga terjadi produksi TNF $\alpha$, IL-1, IL-6 dan IL-8. ${ }^{10,11}$

Beberapa penelitian tentang status gizi pada DBD yaitu Thisyakorn dan Nimmannitya ${ }^{12}$ melaporkan malnutrisi kalori dan protein derajat ringan akan terhindar dari SSD. Pichainarong, $\mathrm{dkk}^{13}$ melaporkan pasien obese memiliki risiko menderita DBD derajat berat lebih tinggi. Namun penelitian di Yogyakarta oleh Sugiyanto, dkk tahun 1983, di Thailand tahun 1993, dan di Taiwan tahun 2005 didapatkan bahwa status gizi tidak mempengaruhi derajat berat ringannya penyakit. ${ }^{9,14}$ Begitu juga Ganda dkk ${ }^{15}$ di Makasar melaporkan tidak ada perbedaan status gizi antara kelompok DBD dan DBD dengan syok.

\section{Metode}

Penelitian dengan rancangan kasus kontrol, mengambil data dari rekam medik pasien DBD yang dirawat inap di Bagian Anak, Rumah Sakit Umum Pusat (RSUP) Sanglah, Denpasar, Bali mulai tanggal 1 Januari sampai 31 Juli 2008. Kasus adalah semua anak pasien SSD berdasarkan kriteria WHO 1999 yang memenuhi kriteria inklusi dan eksklusi sedangkan kontrol adalah anak pasien DBD, non DSS pada periode yang sama dipilih secara consecutive sampling. Kriteria inklusi yaitu anak yang didiagnosis DBD termasuk SSD dan usia kurang dari 12 tahun sedangkan kriteria eksklusi yaitu catatan medik pasien tidak lengkap dan pasien DBD disertai dengan penyakit lain seperti pneumonia berat, diare dengan dehidrasi berat, palsi serebral, gizi buruk, ensefalitis, dan gangguan ginjal.

Data yang terkumpul diuji dengan statistical product and service solution (SPSS) 14 dengan tingkat kemaknaan apabila $p<0,05$ dan interval kepercayaan (IK) $95 \%$. Data kategorik pada karakteristik dasar dilakukan uji Chi square atau alternatifnya, sedangkan data numerik dengan uji t atau alternatifnya. Rasio odds dihitung untuk mengetahui besarnya risiko SSD pada pasien obesitas. Analisis multivariat dilakukan terhadap faktor-faktor lain yang berpengaruh terhadap terjadinya SSD.

\section{Hasil}

Selama periode penelitian 74 orang pasien SSD dirawat di bagian anak, RSUP Sanglah Denpasar. Dari 74 kasus SSD, 6 orang datanya tidak lengkap, 1 orang disertai dengan penyakit lain, dan 16 orang dengan status gizi buruk. Karakteristik dasar kedua kelompok tidak berbeda bermakna dengan $p>0,05$ tertera pada Tabel 1.

Pada Tabel 2 terlihat 78,9\% pasien obese mengalami SSD, sedangkan SSD pada pasien nonobese 43,4\% $(p=0,005)$. Perbedaan kejadian SSD antara kelompok anak obese dengan non-obese $35,5 \%$ dengan rasio odds 4,9 (IK 95\% 1,5-16,0). 
Tabel 1. Karakteristik dasar subjek penelitian

\begin{tabular}{lccc}
\hline Variabel & $\begin{array}{c}\text { Kasus/SSD } \\
\mathrm{n}=51\end{array}$ & $\begin{array}{c}\text { Kontrol/nonSSD } \\
\mathrm{n}=51\end{array}$ & $p$ \\
\hline Umur (tahun), rerata (SD) & $7,5(2,5)$ & $7,7(2,9)$ & 0,767 \\
Jenis kelamin & & & \\
$\quad$ Laki-laki & $26(51)$ & $27(52,9)$ & 0,843 \\
$\quad$ Perempuan & $25(49)$ & $24(47,1)$ & \\
BB (kilogram), rerata (SB) & $29,5(13,0)$ & $26,4(12,2)$ & 0,230 \\
TB (sentimeter), rerata (SB) & $124,3(16,9)$ & $123,7(19,8)$ & 0,860 \\
Jenis infeksi, n (\%) & $1(2)$ & $4(7,8)$ & \\
$\quad$ Primer & $43(84,3)$ & $33(64,7)$ & 0,693 \\
$\quad$ Sekunder & $7(13,7)$ & $14(20,6)$ & \\
$\quad$ Kemungkinan sekunder & & & \\
Outcome, n(\%) & $49(96,1)$ & $50(100)$ & 0,495 \\
$\quad$ Sembuh & $2(3,9)$ & $0(0)$ & \\
$\quad$ Meninggal & &
\end{tabular}

SB : simpang baku

Tabel 2. Perhitungan rasio Odds

\begin{tabular}{lcccc}
\hline & & \multicolumn{2}{c}{ DBD (n, \%) } & \multirow{2}{*}{ Jumlah } \\
\hline \multirow{2}{*}{ Status Gizi } & Obese & $15(78,9)$ & $4(21,1)$ & $19(100)$ \\
& Non obese & $36(43,4)$ & $47(56,6)$ & $83(100)$ \\
\hline \multirow{2}{*}{ Jumlah } & & 51 & 51 & 102 \\
\hline
\end{tabular}

Tabel 3. Analisis multivariat beberapa faktor yang berpengaruh terhadap SSD

\begin{tabular}{lcccc}
\hline Variabel & $\mathrm{B}$ & $p$ & Rasio odds & IK 95\% rasio odds \\
\hline Umur & 0,35 & 0,647 & 1,035 & $0,892-1,202$ \\
Jenis kelamin & $-0,143$ & 0,733 & 0,867 & $0,383-1,969$ \\
Jenis infeksi & 0,317 & 0,467 & 1,373 & $0,584-3,229$ \\
Status gizi & 1,595 & 0,009 & 4,927 & $1,495-16,238$ \\
\hline
\end{tabular}

Analisis multivariat dilakukan terhadap faktorfaktor yang berpengaruh terhadap terjadinya SSD yaitu umur, jenis kelamin, jenis infeksi, dan status gizi dengan menggunakan regresi logistik. Setelah dilakukan analisis, didapatkan hanya status gizi yang bermakna berpengaruh terhadap terjadinya SSD dengan $p=0,009$, seperti tertera pada Tabel 3 .

\section{Diskusi}

Rerata umur pada kelompok SSD 7,5 $\pm 2,5$ tahun. Penelitian yang dilakukan oleh Ganda $\mathrm{dkk}^{15}$ di Makasar

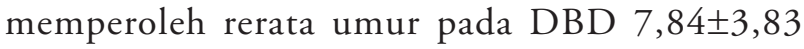

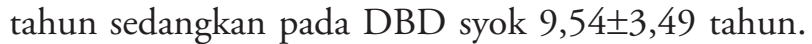
Proporsi kasus DBD menurut kelompok umur di Indonesia tahun 1993-1997 tertinggi pada usia sekolah (5-14 tahun) 60\%. Penelitian Ganda dan Bombang ${ }^{16}$ melaporkan pasien SSD yang terbanyak pada kelompok 6-15 tahun (60\%). Namun di RS M Hoesin dan Charitas, Palembang, Sumatera Selatan mendapatkan infeksi dengue terbanyak pada usia 1015 tahun (59\%). ${ }^{17}$ Pada epidemi dengue pertama di Bangkok dan epidemi DBD pertama di Gorontalo, Sulawesi, yang terkena terutama anak-anak berumur 1-5 tahun. Pergeseran kejadian DBD dari usia kurang 5 tahun menjadi lebih 5 tahun bahkan dewasa berhubungan dengan teori secondary heterolog infection 
bahwa penyakit akan muncul apabila seseorang setelah terinfeksi virus dengue untuk pertama kali kemudian mendapatkan infeksi kedua dengan virus dengue serotipe lain dalam jarak waktu 6 bulan sampai 5 tahun. ${ }^{\text {? }}$

Berdasarkan jenis kelamin, tidak ada perbedaan bermakna antara laki-laki dan perempuan pada kedua kelompok. Hasil penelitian ini sama dengan penelitian-penelitian sebelumnya yang dilakukan oleh Ganda dan Bombang (2005), Ganda dkk (2006) di Makasar. ${ }^{15,16}$ Wills dkk ${ }^{18}$ mendapatkan tidak ada perbedaan jenis kelamin pada SSD baik derajat ringan maupun berat.

Jenis infeksi sekunder merupakan infeksi terbanyak pada SSD dan DBD yaitu lebih dari 50\% kasus. Sesuai dengan hipotesis infeksi sekunder dengan serotipe lain yang berurutan sebagai dasar teori yang banyak dianut. Pichainarong $\mathrm{dkk}^{13}$ dalam penelitiannya mendapatkan kejadian infeksi sekunder $90,5 \%$ pada SSD dan $88,6 \%$ pada DBD. Pada kejadian luar biasa (KLB) tahun 2004 di Jakarta, infeksi sekunder terjadi $82,5 \% .{ }^{19}$

Obesitas berpengaruh terhadap kejadian SSD dengan rasio odds 4,9 (IK 95\% 1,5-16,0). Pengaruh obesitas terhadap DBD dan SSD masih kontroversi. Kasus SSD paling banyak ditemukan pada anak dengan status gizi baik dan sangat jarang pada gizi buruk. Beberapa penelitian secara konsisten melaporkan bahwa gizi baik merupakan yang terbanyak pada DBD dan SSD. Tantracheewathorn dan Tantracheewathorn ${ }^{20}$ melaporkan bahwa sebagian besar kasus DBD dan SSD dengan status gizi normal. Kejadian malnutrisi 33,6\% pada DBD dan $27,3 \%$ pada SSD sedangkan obesitas pada SSD terjadi $29,1 \%$ dan $24,5 \%$ pada DBD. Malnutrisi tidak merupakan faktor risiko terjadinya SSD. Status gizi dibagi menjadi 3 kelompok menurut berat badan per umur yang dibandingkan dengan standar nasional pertumbuhan anak Thai yaitu normal, malnutrisi energi protein dan obese. Ganda dkk ${ }^{15}$ mendapatkan bahwa status gizi tidak berpengaruh terhadap DBD dan DBD dengan syok. Pada penelitiannya, status gizi dibagi menjadi 4 kelompok yaitu gizi lebih, baik, kurang, dan buruk. Status gizi kelompok DBD tanpa syok dan DBD syok terbanyak terjadi pada gizi baik yaitu masing-masing 58,3\% dan 45,9\%. Gizi lebih terjadi $5,6 \%$ pada DBD syok dan $8,1 \%$ pada DBD tanpa syok. Kejadian SSD selama 8 tahun dilaporkan oleh Ganda dan Bombang ${ }^{16}$ terbanyak pada status gizi baik yaitu 375 dari 459 SSD (82\%). Gizi kurang 15\% dan gizi buruk $3 \%$. Berbeda dengan penelitian yang dilakukan oleh Kalayanarooj dan Nimmannitya ${ }^{21}$ dengan menggunakan rancang kasus dan kontrol mendapatkan bahwa SSD lebih besar terjadi pada keadaan malnutrisi dibandingkan gizi baik. Status gizi dibedakan menurut skala $\mathrm{BB}$ per umur dan $\mathrm{BB}$ per TB menjadi 3 yaitu normal (rata-rata $\pm 1,5 S D$ ), malnutrisi atau kurus $(\leq 1,5$ SD) dan obese $(\geq 1,5$ SD). Malnutrisi pada DBD 7,9\% sedangkan pada SSD $10,9 \%$. Perbedaan ini berbeda secara bermakna dengan rasio odds $1,43(1,11-1,83) ; p=0,004$. Obese didapatkan $24,5 \%$ pada DBD dan $24,0 \%$ pada SSD. Obesitas tidak mempengaruhi kejadian SSD dengan rasio odds $1,01(0,86-1,2)$ dan $p=0,865$ sedangkan gizi baik merupakan terbanyak yang ditemukan pada kasus DBD dan SSD yaitu masing-masing 67,6\% dan $65,2 \%$. Namun anak obese memiliki risiko lebih besar terinfeksi virus dengue dibandingkan dengan anak malnutrisi. Perbedaan tersebut nyata dengan rasio odds $1,96(1,55-2,5) ; p=0,000$.

Penelitian yang mendukung adalah penelitian yang dilakukan oleh Pichainarong $\mathrm{dkk}^{13}$ dengan menggunakan rancangan kasus dan kontrol. Status gizi dibedakan berdasarkan $\mathrm{BB}$ per umur dan $\mathrm{BB}$ per TB (kurva pertumbuhan standar anak Thai, Departemen Kesehatan 2000) dan obese didefinisikan apabila $\geq 1,5$ SD. Pasien dengan obese memiliki risiko yang lebih besar untuk menderita DBD berat dengan rasio odds sebesar 2,77 (IK 95\% 1,19-6,45) dibandingkan dengan gizi normal.

Hubungan status gizi seseorang erat kaitannya dengan respon imun tubuh namun peran fungsi imun pada obesitas dikatakan masih belum jelas. Obesitas berarti terjadi penumpukan jaringan lemak akibat peningkatan jumlah dan besar sel adiposit. Diantara jaringan lemak yang ada, jaringan lemak putih yaitu sel adiposit jaringan lemak putih yang mensekresikan dan melepaskan sitokin pro-inflamasi TNFa (tumour necrosis factor $\alpha$ ) dan beberapa interleukin (IL) yaitu IL-1 $\beta$, IL-6, dan IL-8. Pada obesitas akan terjadi peningkatan ekspresi TNF $\alpha$ dan IL-6 sedangkan pada SSD terjadi produksi TNF $\alpha$, IL-1, IL-6 dan IL-8. ${ }^{10,11}$ Apakah akibat peningkatan ekspresi TNF $\alpha$ dan IL-6 pada obesitas ini ikut berperan dalam menyebabkan DBD menjadi SSD sehingga keadaan obesitas berisiko lebih tinggi mengalami SSD? Hal ini perlu dikaji lebih lanjut dan dilakukan penelitian berikutnya sehingga dapat menjawab kenapa obesitas merupakan faktor 
risiko terjadinya SSD pada anak.

\section{Kesimpulan dan saran}

Dari penelitian kami, disimpulkan bahwa obesitas adalah faktor risiko terjadinya SSD pada anak. Besarnya risiko SSD pada anak obese 4,9 kali lebih besar dibandingkan dengan anak non-obese. Perlu dilakukan penelitian lebih lanjut tentang pengaruh obesitas terhadap kejadian SSD dengan desain penelitian kohort.

\section{Daftar Pustaka}

1. Darmowandono W. Correlation between humoral immune response and the severity of dengue hemorrhagic fever. Dalam: Kuntaman, Lusida MI, Hargono R, Poernomo B, penyunting. International seminar on dengue fever / dengue hemorrhagic fever in South East Asia. Surabaya: Tropical Center Disease; 1999. h.6875.

2. Hung NT, Lei HY, Lan NT, Lin YS, Huang KJ, Lien LB, dkk. Dengue Hemorrhagic fever in infant: a study of clinical and cytokine profiles. The Journal of Infectious Diseases 2004;189:221-32.

3. Suroso T dan Umar AI. Epidemiologi dan penanggulangan penyakit demam berdarah dengue (DBD) di Indonesia saat ini. Dalam: Sri R, Hindra IS, penyunting. Naskah lengkap pelatihan bagi pelatih, dokter Spesialis Anak dan dokter Spesialis Penyakit Dalam dalam tatalaksana DBD. Jakarta: Balai Penerbit FKUI;2005.h.14-31.

4. Thasan NK, Vaughn DW, Shope RE. Dengue and dengue hemorrhagic fever. Dalam: Gershon AA, Hotez PJ, Katz SL, penyunting. Krugman's infectious diseases of children. Edisi ke-11. USA: Mosby; 2004.h.73-81.

5. Soedarmo SS, Garna H, Hadinegoro SR. Infeksi virus dengue. Buku Ajar Ilmu Kesehatan Anak. Jakarta: Balai Penerbit FKUI; 2002.h.176-207.

6. Karyana IPG. Uji diagnostik rasio $\operatorname{IgG:IgM~untuk~}$ menentukan tipe infeksi dengue dan kadar IgG sebagai prediktor terjadinya sindrom syok dengue akhir sebagai persyaratan untuk mendapatkan tanda keahlian dibidang ilmu kesehatan anak. Bagian/SMF Ilmu Kesehatan Anak. Fakultas Kedokteran Universitas Udayana. RS Sanglah. Tesis 2005.

7. Harun SR. Tatalaksana demam dengue/demam berdarah dengue pada anak. Dalam: Rezeki S, penyunting. Demam berdarah dengue naskah lengkap pelatihan bagi dokter spesialis anak dan dokter spesialis penyakit dalam. Jakarta: Balai Penerbit FK UI; 2000. h. 83-137.

8. Halstead SB. Dengue fever and dengue hemorrhagic fever. Dalam: Behrman RE, Kliegman RM, Jenson HB, penyunting. Nelson Texbook of Pediatrics. Edisi ke-17. Philadelphia: W.B Saunders Company; 2004.h.109294.

9. Sutaryo. Dengue. Yogyakarta: Medika Fakultas Kedokteran Universitas Gadjah Mada; 2004.

10. Trayhurn P, Wood LS. Signalling role of adiposetissue: adipokines and inflammation in obesity. Biochemical Society Transactions 2005;33:078-81.

11. Coppack SW. Pro-inflammatory cytokines and adipose tissue. Proceedings of the nutrition society 2001;60:34956.

12. Thisyakorn U, Nimmannitya S. Nutritional status of children with dengue hemorrhagic fever. Clin Infect Dis 1993;16:295-7.

13. Pichainarong N, Mongkalangoon N, Katayanarooj S. Chaveepojnkamjorn W. Relationship between body size and severity of dengue hemorrhagic fever among children aged 0-14 years. Southlast Asian J Trop Med Public Health 2006;3:283-8.

14. Hung NT, Lan NT, Lei HY, Lin YS, Lein LB, Huang $\mathrm{KJ}$, dkk. Association between sex, nutritional status, severity of dengue hemorrhagic fever, and immune status in infants with dengue hemorragic fever. Am J Trop Med Hyg 2005;72:370-4.

15. Ganda IJ, Boko SH, Daud D. Comparison of blood gases analysis in patient with dengue shock syndrome and dengue hemorrhagic fever. J Med Nus 2006;27:151-5.

16. Ganda IJ, Bombang H. Morbiditas dan mortalitas sindrom syok dengue di Pediatric Intensive Care Unit (PICU) Bagian Ilmu Kesehatan Anak Rumah Sakit Dr. Wahidin Sudirohosodo Makassar Januari 1998Desember 2005. J Med Nus 2005;26:244-50.

17. World Health Organization. Dengue, Dengue haemorrhagic fever and dengue shock syndrome in the contex of the integrated management of childhood illness. Department of Child and Adolescent Health and Development 2005.

18. Wills BA, Oragui EE, Dung NM, Loan HT, Chau NV, Farrar JJ, dkk. Size and charge characteristics of the protein leak in dengue shock syndrome. J Infect Dis 2004;190:811-8. 
19. Setiati TE, Wagenaar JFP, De Kruif MD, Mairuhu ATA, Van Gorp ECM, Soemantri A. Changing epidemiology of dengue haemorrhagic fever in Indonesia. Dengue Buletin 2006; 30:1-14.

20. Tantracheewathorn T, Tantracheewathorn S. Risk factors of dengue shock syndrome in children. J Med Assoc Thai 2007;90:272-7.

21. Kalayanarooj S, Nimmannitya S. Is dengue severity related to nutritional status. Southlast Asian J Trop Med Public Health 2005;36:380-4. 